\title{
Native grasslands of the Mesopotamia region of Argentina
}

\author{
D. H. van der Sluijs \\ FAO Grassland Ecologist 1
}

Received: 13 July 1970

\section{Summary}

The grazing industry in the Mesopotamia region of Argentina depends on natural grasslands whose main characteristics are intermediate between the drier grasslands of warmer climates and the better, more humid grasslands of temperate regions. This is borne out by the floristic composition of these grasslands, their productivity and finally by their potential to respond to improved management. Special conditions, of socioeconomic order, are however providing insufficient incentives to the average producer of the region to increase the production from these grasslands.

In this paper a description is given of the major grassland types, their characteristics and the ecological conditions.

Some of the factors which deserve special attention in future development planning are discussed.

\section{Introduction}

Because of the extent of the region (some $150.000 \mathrm{~km}^{2}$ or nearly $5.4 \%$ of the country's total area), its natural conditions and also its relatively isolated position, extensive grazing has played an important part in the region over many years. Early records of domestic grazing date back as far as 1573.

The livestock industry for the whole country in 1967 represented $30 \%$ of the overall agricultural production. The total agricultural production for that year amounted to nearly 2,000 million dollars. For the two provinces here under discussion, Corrientes and Entre Ríos, the following figures apply: The livestock industry in Corrientes and Entre Ríos represented in 196754.9 and $59.2 \%$, respectively, of the agricultural production. Beefcattle production in the two provinces made up for 45.6 and $26.5 \%$, respectively, of the total livestock industry, and woolsheep for only 5.7 and $1.8 \%$, respectively (Banco Ganadero Argentino, 1968).

From available statistics it was calculated by Hutchison (1968) that the region is populated by 6.4 million animal units ( $\mathrm{AU}$ ) of cattle and sheep, $1 \mathrm{AU}$ being the equivalent of 1 mature cow of $401-450 \mathrm{~kg}$ (Hutchison and Frame, in press). An additional 900,000 horses bring the total livestock population for the region to some 7 million $\mathrm{AU}$.

Land-use in the region is illustrated by the figures of Table 1. Those figures refer to the area classified as agricultural land. Estimates by the FAO team to which I belonged, on annual production of dry matter were $3000 \mathrm{~kg} / \mathrm{ha}$ for natural grassland, 1000 and $5000 \mathrm{~kg} / \mathrm{ha}$, respectively, for annual and perennial fodder. It is difficult to

1 Grassland Ecologist (Survey) with FAO until March 1969, lastly stationed at Concepción del Uruguay, Entre Rios, Argentina. Present address: Range Science Department, Colorado State University, Fort Collins, Colorado, USA. 
Table 1. Land utilization in the Mesopotamia region (in ha).

\begin{tabular}{lrrr}
\hline Land-use & Entre Rios & Corrientes & Total region \\
1. Woodland & $1,004,464$ & 562,716 & $1,567,180$ \\
2. Treeless grassland & $3,928,563$ & $4,831,605$ & $\mathbf{8 , 7 6 0 , 1 6 8}$ \\
3. Annual fodder & 213,176 & 6,545 & 219,721 \\
4. Perennial fodder & 155,524 & 1,133 & 156,657 \\
5. Wasteland & 332,466 & 561,794 & 894,260 \\
6. Suitable for agriculture or & 366,265 & 260,826 & 627,091 \\
grazing, but unused & & & 71,608 \\
7. Houses, sheds, etc. & 43,711 & 27,897 & 130,076 \\
8. Permanent crops & 89,399 & 40,677 & 973,183 \\
9. Annual crops & 818,321 & 154,862 & \\
\hline
\end{tabular}

Source: Censo Nacional Agropecuario 1960.

estimate what is the contribution of grazing derived from the nearly 1 million ha of stubble (Item 9 of Table 1) and of part-time grazing derived from the 894.260 ha classified as wasteland (Item 5 of Table 1). Undoubtedly, however, these two categories of grazing land do, qualitatively and quantitatively, constitute an important additional grazing resource.

In the following pages a brief outline will be given of the ecological conditions which characterize the region and which form the setting for the grazing industry.

\section{a. Location (see Map 1)}

The Corrientes and Entre Ríos provinces are two of the twenty-two provinces into which the Argentine Republic is subdivided administratively. They are located in the north-east of the country. Misiones, which forms the most northeastern sector of the country as a 'wedge' between Paraguay and Brasil, is sometimes also included in what is referred to as the Mesopotamia region. In this paper the term will refer to the two first mentioned provinces only.

The region, as suggested by the name, is surrounded by two large rivers which both have their headwaters in Brasil. The Uruguay river forms the eastern boundary and is also the boundary of Argentina with Brasil and Uruguay. The second river, the Parana, makes in its middle course two sharp bends, namely at Posadas (the capital of the Misiones province) from where the river follows an east-west course up to Corrientes city (the capital of Corrientes province. Here the Paraguay joins the Parana. Over this distance, between Posadas and Corrientes, the river forms the boundary between Argentina and Paraguay. From Corrientes city onwards the river flows almost due south to Paraná (the capital of Entre Ríos) whence a large delta (of some $20,000 \mathrm{~km}^{2}$ ) spreads out along the southern sectors of the region. The waters of the Paraná (through the delta) and of the Uruguay river flow out into the River Plate (Rio de La Plata), north of Buenos Aires.

The area thus outlined is located between 27 and $34^{\circ} \mathrm{S}$ and covers some 15 million ha, with about 1.5 million inhabitants. Of this population $37.5 \%$ is engaged in agriculture.

Communications into and within the region are poor, being too vulnerable to climatic conditions, especially when it is realized that $80 \%$ of the region's contribution in cattle for the Buenos Aires and export market is moved out of the region by truck, the remainder by rail. Very few roads within the region are paved, the paved sections being mostly limited to roads leading into some of the major towns. Trunk roads, especially those through the eastern half of the region, are usually provided with a thin cover of river terrace gravel from alluvial deposits of the Uruguay river. Such roads are therefore trafficable during the greater part of the year, though wear on tires and vehicles is high. The major bottleneck consists, however, in the connections of the region with the rest of the country, and this applies particularly to the north-south communication with the Buenos Aires province and the capital itself. Here the major local consumption market is found while all but a very small proportion of the exports are dealt with through Buenos Aires. The two ferry-boat crossings which have to be made by all south-bound traffic (across the two major delta arms) cause delays varying from one to twentyfour hours.

\section{b. Climate}

Natural conditions are characterized by a climate that is transitional in the south towards a cold 
NATIVE GRASSLANDS OF THE MESOPOTAMIA REGION OF ARGENTINA

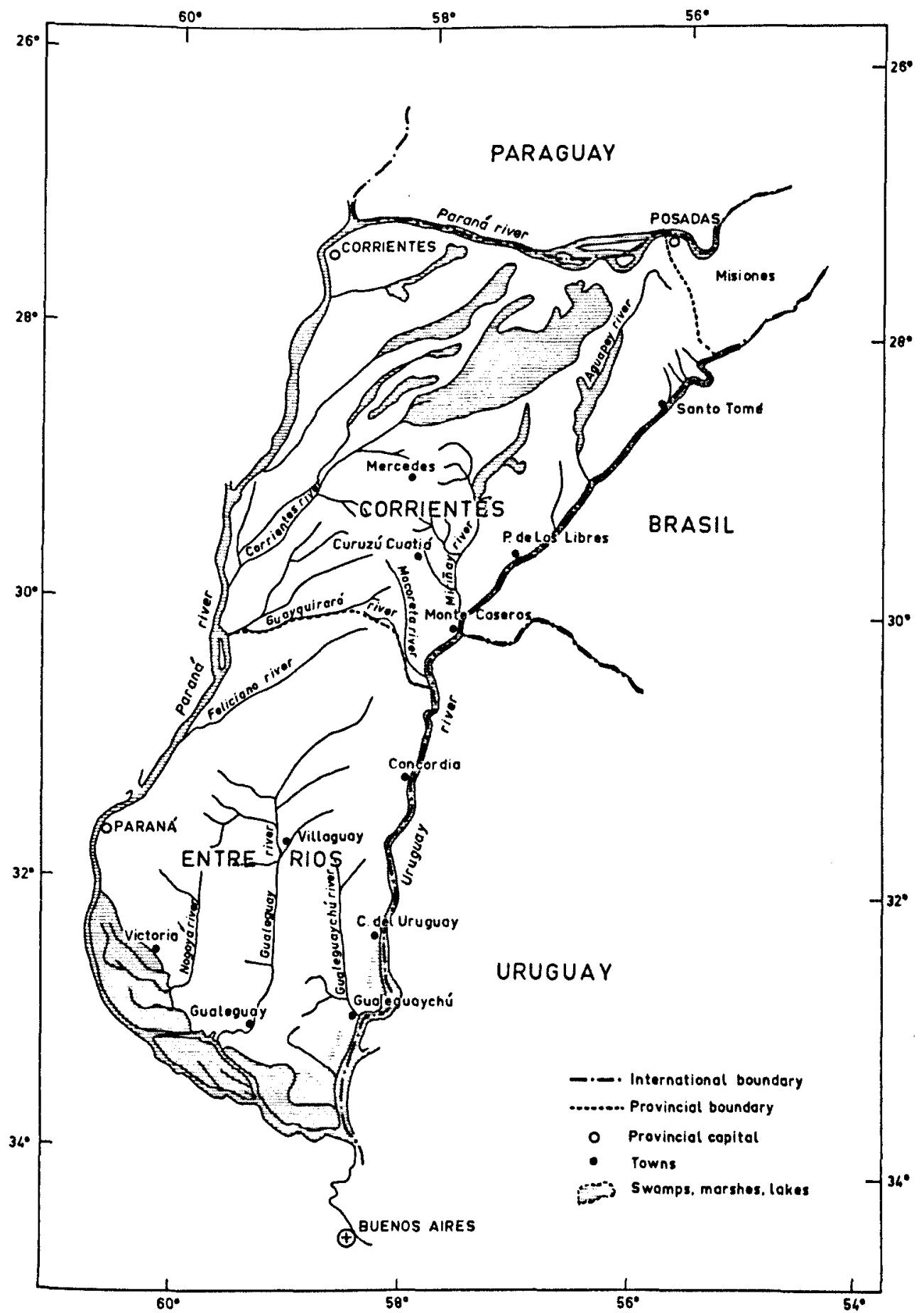

Map 1. Mesopotamia region (geographic). Scale $1: 6,450,000$.

Neth. J. agric. Sci. 19 (197I) 


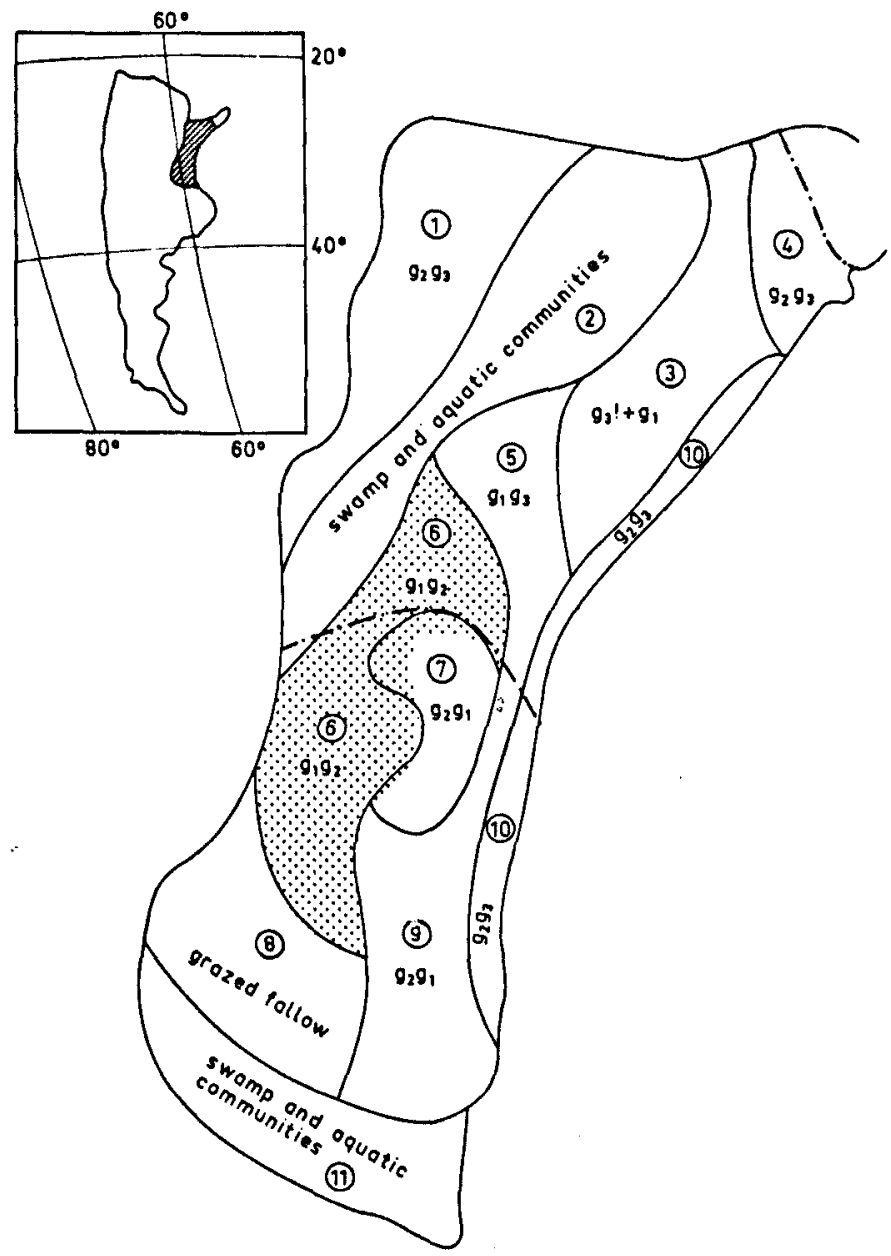

Map 2. Mesopotamia region: major grassland zones.

Key to symbols used: $g_{1}$ short grassland; ge medium tall grassland; ga tall, tussock grassland; g ! 'malezal'. A combination of two symbols (e.g. $g_{2} g_{1}$ ) refers to a vegetation mosaic of two grassland types. Shaded area: sclerophyll woodland (Prosopis-Acacia).

- . . - provincial boundary.

Scale $1: 9,400,000$.

See text for further explanation.

steppe climate and in the north towards a cool tropical climate. Average annual rainfalls range from about $950 \mathrm{~mm}$ in the south to $1650 \mathrm{~mm}$ and over in the north-east.

For all localities the winter season is the period of least rainfall, but the lower temperatures markedly reduce evaporation. Periods of three to five consecutive months with a negative water balance (more potential evaporation than rainfall) occur from late spring to early autumn for most localities except for those in the more subtropical parts of the region in northern Corrientes. An annual negative water balance exists for the southern three quarters of the region, below a line which coincides approximately with the $1200 \mathrm{~mm}$ isohyet. It is particularly in this area that periods of drought may cause serious depressions in crop yields and - in the livestock sector - are responsible for losses in weight and death losses. Such droughts in their severity and effect are the combined result of climatic and edaphic conditions.

Another characteristic of the regional climate are heavy, concentrated showers. The significance 
of this is that total and even daily rainfall figures may give an incomplete or insufficiently clear picture of the amount of moisture that is available to the growing plant. Such heavy rainfall, combined with the characteristic low permeability of the principal soils (grumusols) and the gentle topography, causes that the effective rainfall is considerably lower than average rainfall figures would suggest. Excessive run-off in the more sloping country and impermeable layers causing periodically high water tables in the flatter areas are therefore common.

Although winters are mild throughout the region, groundfrosts occur everywhere. The average time per year with frost decreases pronouncedly from over 10 days in the south to 0.2 days in the northwest (Corrientes city). The period over which frosts may occur shows a similar trend, and is of 5 to 6 months duration in the south (May-October) and from 1 to 3 months (May-August) in the north. 'Severe' frosts were recorded in June 1966, when e.g. Concepción del Uruguay, with an absolute minimum shade temperature of $-4^{\circ} \mathrm{C}$ over the period $1951-1960$, registered temperatures of $-7.1^{\circ} \mathrm{C}$.

Precipitation never reaches the earth surface in the form of snow, but short, heavy hail storms are a well-known feature, especially during autumn and early winter months. Individual stones were recorded to weigh up to $150 \mathrm{~g}$ and have a diameter of $5-7 \mathrm{~cm}$ (July 1967).

Average monthly shade temperatures (over the period 1951-1960) ranged from $17.6^{\circ} \mathrm{C}$ in the south to $21.5^{\circ} \mathrm{C}$ in the north-west, with lowest temperatures in June and July. Summers are on the average warm, with absolute maximum shade temperatures above $40^{\circ} \mathrm{C}$ throughout the region.

\section{c. Land forms, geology and soils}

The oldest known geological formation consists of hard, layered and often silicified red sandstone of aeolian origin, very resistant to weathering, and basic volcanic rock, which decomposes more readily than the sandstone, when exposed. These rocks of Triassic (Secondary) age form the basement complex in most of the region, often found at great depth. In southern Entre Rios, for instance, the basalt is found at between 400 and $450 \mathrm{~m}$ depth (Cordini, 1949). The sandstone forms the parent material from which red lateritic (kaolinitic) clays, common in northeast Argentina (Misiones province) and southern Brasil, have developed. Outcrop of the same Triassic sandstone and to a lesser extent of the basalts is found in the centre of Corrientes province, between Mercedes and Curuzu Cuatiá. Actual drainage patterns, outcropping rock in a few other places (e.g. along the Uruguay river valley as far south as Concordia) and the depth at which it is found in other places, are all proof for tectonic movements and active faulting processes which continued into the Quaternary (Pleistocene) and which played an important role in the shaping of the present landscape. Marine ingressions during the Pliocene (Tertiary) covered much of Entre Rios (Cordini, 1949). After the sub. sequent tectonic uplift the Uruguay and Paraná rivers took their present courses, and at the same time the central divide between these two rivers, the Mercedes plateau, was formed (Bonarelli and Longobardi, 1929). These movements did leave behind large areas in northwest and southeast Corrientes with a very poorly developed drainage system. In general drainage is much better developed in Entre Ríos and rivers have more incised channels with narrower floodplains than the rivers in Corrientes. Poorly drained flat lands are, however, also found in the north-centre of Entre Rios.

The following landscapes and parent materials for the major soils of the region may be distinguished:

1 Northwest Corrientes is covered mainly by sandy and clayey alluvium of Holocene age, layed down in a pattern of low, dune-like ridges which consist of sand overlying impermeable clay and running northeast to southwest. This area represents the former delta of the Parana river (Bonarelli and Longobardi, 1929). Another feature are the innumerable ponds and lakes which, though rather shallow, are mostly permanent. Included is a rather inaccessible area of swamps and marshes, called the 'Esteros del Ibera', covering about $5,200 \mathrm{~km}$. Holocene sediments are also found along the Aguapey river valley through which the Parana river used to flow into the Uruguay river.

2 A second flat, ill-drained area is found in the cast of Corrientes, where mixed sandy clay deposits of fluvio-lacustrine origin and of Pliocene age are found. This constitutes a very particular grassy landscape without tree growth, locally called 'malezal' (Fig. 1).

3 The watershed between the two main river systems is formed by the area with sandstone outcrop in the centre of Corrientes province. Maximum elevation here (just south of Mercedes) is $140 \mathrm{~m}$ above sea level. Soils may have sandy textures or an admixture of sand, deriving from the locally outcropping sandstone, but generally they have developed from basalt as well as from a number of other more recent sediments, namely clayey Pliocene and Pleistocene deposits.

4 Pleistocene deposits, the so-called Pampean loess and 'limos' (silts ; loess, redeposited by water) cover most of Entre Ríos and parts of southern Corrientes (Teruggi, 1957). They form the black, cracking clays (Grumusols) and the lighter-textured Brunizems (formed from the 'primary' loess) which are found in western Entre Rios around Parana. Smooth Iand forms are characteristic: the landscape is undulating or gently undulating except around stream valleys and drainage depressions with their incised and erosive channels.

5 Geologically the present delta of the Paraná river forms a mixture of alluvial deposits of Holo- 


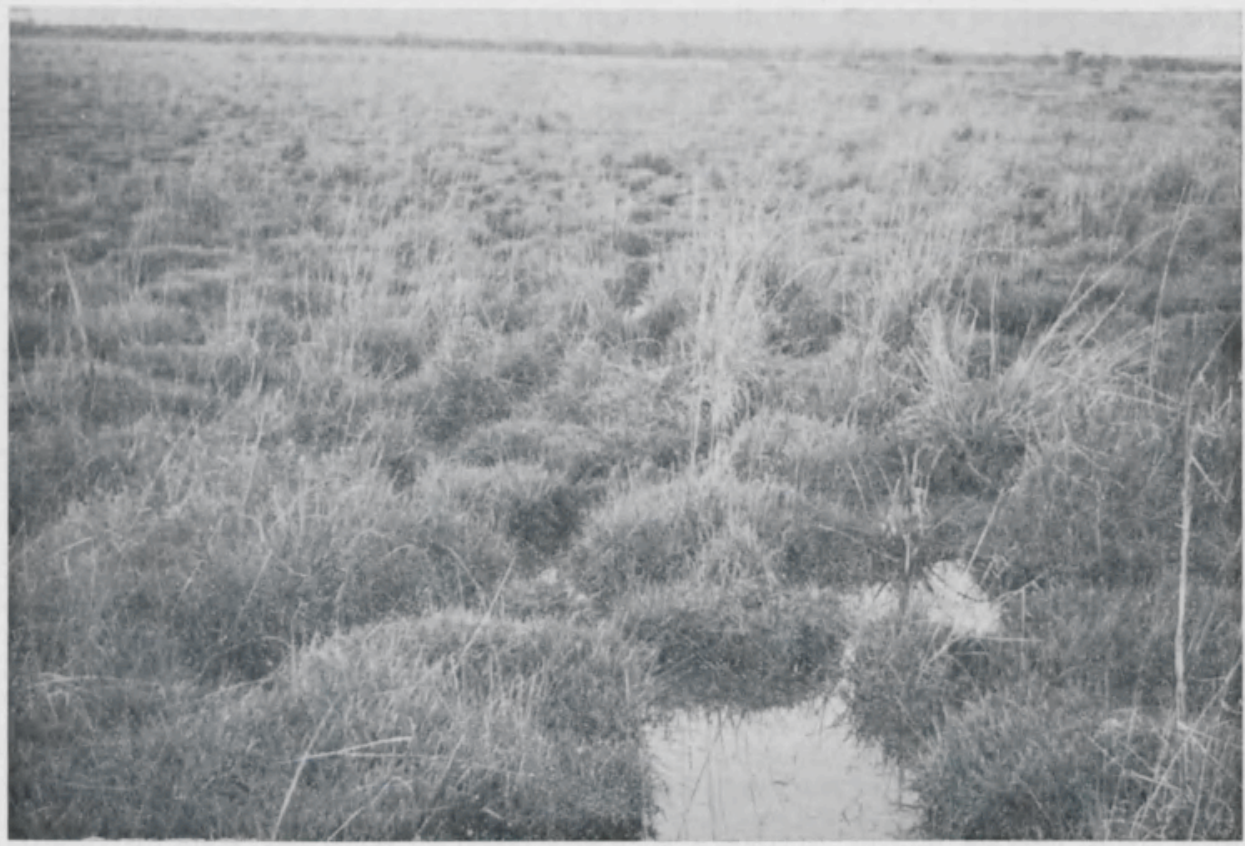

Fig. 1. Marshy grassland, locally called 'malezal', covers extensive areas in the northeast of the Mesopotamia region (Zone 3 ).

cene age laid down in an intricate pattern, typical for deltas. The fact that steep and high cliffs are found along the southern border of the mainland of Entre Ríos (between Parana and Victoria) indicates that the river level has descended relative to the mainland. This is also the reason for the streams draining southwards into the delta, to be strongly and actively erosive. Soils in this area are non-gravelly and fine-textured silts and loams (Bonfils, 1962).

6 The Uruguay river valley also reflects previous conditions during which this river used to flow through a much wider bed than it presently does. This has left behind a series of terraces with gravelly, sandy and clayey deposits in a belt of varying width $(5-20 \mathrm{~km})$. The topography of this zone is undulating to strongly undulating. Outcrop of coarse-grained, silicified yellow sandstone of Pliocene/ Pleistocene age, is common in places.

While conditions in Corrientes province are far more heterogeneous than in Entre Ríos, there exists a common factor, namely poor drainage, which is sufficiently restrictive as to restrict land-use for larger areas to grazing. This applies particularly to the areas with deposits described under I and 2 above, with soils classified as Gray Hydromorphic Soils, Claypan Planosols, Low Humic Gleys and Sandy Regosols (Purnell, 1969). Common in western Corrientes are shallow sandy Regosols over impermeable clay.

In central and southern Corrientes drainage is much better developed and external drainage of the soils is accordingly better on the average than in the above mentioned areas. Edaphic conditions are, however, variable and complex due to the fact that very different parent materials are found together. Predominant soils here are Grumusol and Brunizem intergrades, and soils with planosolic development (Purnell, 1969).

The typical soils for Entre Ríos are Grumusols, while Brunizems are found in the south-west.

The soil and vegetation studies which were carried out have shown the importance of local topography as differentiating factor in the natural environment and particularly in the areas with Grumusols.

\section{d. Vegeration}

The natural vegetation types and their distribution give important indications with regard to the general conditions for plant growth within the region. Those interrelationships were studied in most detail 
for the natural grasslands of the region. The method which was adopted for the survey was the Australian land system method as described by Christian and Stewart (1953) and Chirstian $(1958 ; 1959)$.

Major vegetation types found in the region are:

1 Medium-tall grass savanna $(30-80 \mathrm{~cm})$ with remnants of depauperate Subtropical Forest on the better drained, lateritic soils in the northern sectors of the region;

2 Humid and wet tussocky grasslands with grasses of up to $2 \mathrm{~m}$ in height, found on poorly drained soils and soils with a permanently high water table, e.g. flood plains;

3 Sclerophyll woodland, characterized by thorny species of Prosopis and Acacia, up to $10 \mathrm{~m}$ high, but usually, due to site conditions and woodland exploitation, only 3 to $5 \mathrm{~m}$ high. The ground cover consists of short and medium-tall grasslands, less than $50 \mathrm{~cm}$ and on the average only 10 to $20 \mathrm{~cm}$ high. Composition is very variable. This vegetation type is typical for the areas with Grumusols and their intergrades;

4 Forest along the main river banks throughout the region and along the many branches of the Paraná river in the southern delta areas.

e. Land-use

Early records on the livestock industry in the region date back as far as 1573, when settlers from the Santa Fé area (on the right bank of the Paraná river, opposite Paraná city) moved into western Entre Ríos. During the second half of the 19th Century several agricultural colonies, formed by settlers of European origin, were established mostly in southern Entre Ríos. Wheat was in those days the most important crop grown. Other agricultural crops presently grown are linseed, rice, maize, sorghum, oats and sunflower, whereas crops such as citrus, tung and mate (Ilex paraguensis) emphasize the transitional character of the conditions, namely from subtropical in its northern sector to humid temperate in the south.

The proportion of land planted to agricultural crops is, however, small when compared to the area dedicated to grazing and fodder crop production. Corrientes province has over 5 million ha of natural and sown pasture and fodder against less than 0.2 million ha under annual and perennial crops. Entre Ríos, with a total grazing resource of 5 million ha, has about 1 million ha of land used for agricultural purposes (see Table 1). The comparative values of the livestock industry and agriculture are illustrated by the data on Table 2.

Of the region's total population of bareley 1.5 million people about $37.5 \%$ is engaged in agriculture. Farms are large, even for an area where the average stocking rate on unimproved natural grassland is 0.5 to $0.7 \mathrm{AU} / \mathrm{ha}$. According to data from the Agricultural Census (Censo Nacional Agropecuario, $1960), 75 \%$ (or $4,753,961$ ha) of the allocated land in Corrientes province is held within $5.7 \%$ (1181 farms) of the properties. The corresponding figures for Entre Ríos are $49 \%(3,229,675$ ha) held within $3.3 \%$ (1062 farms) of all the properties. Table 3 shows the distribution of land, also for the small and medium classes.

The figures just presented do also illustrate the existing differences in conditions between the north (with a warmer climate; coarser grasslands; less agriculture) and the south (with a more temperate cllimate; less heterogeneous edaphic conditions; medium-tall grasslands of higher nutritive value; more agriculture).

\section{Grassland research as the basis for livestock development and planning}

In traditional grazing areas of the world the primary aim of livestock industry is not generally to obtain a sustained optimum production of animal products (meat, milk or wool) through adequate management of both the animal and grazing resources. People in such areas (e.g. India, Africa, parts of Argentina, extensive areas in the USA some 30-40 years ago) frequently keep cattle for social prestige, for religious reasons or for economic security (walking bank account). The consequence of these attitudes is un-

Table 2. Value of production (in millions of pesos) $t$.

\begin{tabular}{llll}
\hline & Entre Ríos & Corrientes & Total region \\
Total agricultural production & 48,469 & 16,778 & 65,247 \\
Agriculture only & 19,737 & 7,562 & 27,299 \\
Livestock industry only & 28,732 & 9,216 & 37,948 \\
\hline
\end{tabular}

1 Data for the year 1967 (1 US dollar = 350 Arg. pesos). Source: Banco Ganadero Argentino, 1968 . 
Table 3. Distribution of land according to farm size classes.

\begin{tabular}{|c|c|c|c|c|c|c|c|c|}
\hline \multirow{2}{*}{$\begin{array}{l}\text { Size class } \\
\text { (in ha) }\end{array}$} & \multicolumn{4}{|c|}{ Corrientes } & \multicolumn{4}{|c|}{ Entre Ríos } \\
\hline & $\begin{array}{l}\text { farms } \\
\text { number }\end{array}$ & $\%$ & $\begin{array}{l}\text { area } \\
\text { ha }\end{array}$ & $\%$ & $\begin{array}{l}\text { farms } \\
\text { number }\end{array}$ & $\%$ & $\begin{array}{l}\text { area } \\
\text { ha }\end{array}$ & $\%$ \\
\hline$<100$ & 15,835 & 78.1 & 354,358 & 5.5 & 21,675 & 67.1 & 941,872 & 14.3 \\
\hline $100-1000$ & 3,285 & 16.2 & $1,099,863$ & 18.0 & 9,552 & 29.6 & $2,414,077$ & 36.7 \\
\hline$>1000^{1}$ & 1,181 & 5.7 & $4,753,961$ & 76.5 & 1,062 & 3.3 & $3,229,675$ & 49.0 \\
\hline Total & 20,301 & 100.0 & $6,208,182$ & 100.0 & 32,289 & 100.0 & $6,585,624$ & 100.0 \\
\hline
\end{tabular}

I Farms with over 10,000 ha of land are not uncommon.

regulated grazing, leading to serious deterioration of large tracts of natural grazing lands. The damage which has been and still is being caused to the vegetation-soil complex in this way is only just beginning to be appreciated in some of those areas.

Through improved methods of grazing it is in general possible to turn the tide, but there is a number of factors which are decisive for the success of measures to be taken. Quite often has the biotic factor operated over such a long period that although it may be possible to stop further degradation rather effectively, the return to a stable, protective and productive vegetation cover will require much time and capital. But perhaps the most important of all is in this respect the attitude of the local people and their preparedness to modify traditional methods and ways of thinking into better metthods and approaches.

This in turn requires frcm Governments and from research workers a thorough understanding of the nature and scope of the problems, both in their technical and social aspects. While in general there is little question as to what are the optimum feeding requirements for the livestock, the real problem is how to meet these at all times. Well-planned surveys are usually required to define the extent of the grazing resource in space and in time. That is to say that the geographical distribution of the different types of grazing land and their yearround production curves have to be defined.

The saying 'pedigree enters through the mouth' in a somewhat simplified way indicates the correct order of priorities, as a reaction indeed to many livestock development programmes in which too much emphasis is placed on introduction and animal breeding programmes, and too little on the study and evaluation of the grazing resource.

Several approaches exist to collect the information needed to make right decisions. The information required will vary from one area to another, according to the local, regional and national situation and conditions, including existing development plans. Where large areas are involved - and such is usually the case in the study of natural grasslands - an integrated type of survey is the best approach, especially when aerial photography (preferably of an intermediate scale of between $1: 50,000$ and $1: 100,000$ ) is available. Such a survey, when properly planned and carried out by an adequate team, with at least a soils and vegetation specialist (ecologist), can in relatively short time assemble a map of land types or land systems, together with a description of the major soils and vegetation types, and their interrelationships. Grassland studies often reveal that particularly variations in soil moisture and water-holding capacity (which find an expression in profile characteristics such as texture, presence and depth of manganese and calcium carbonate concretions, mottling and gleying) are strongly correlated with grassland type or site. This is also the case in the Mesopotamia region 
of Argentina, where moisture availability - as a function of climatic and soil conditions - is a major factor in classifying and subdividing the grasslands for utilization and management purposes.

\section{The major grassland types and their ecology}

As was seen previously the Mesopotamia region has over 10 million ha of natural grassland. Much of this is open, treeless grassland, but woody grasslands and grassy woodlands are also found. In those central parts of the region which are still covered by sclerophyll woodland (Map 2, shaded area) the tree layer does rarely prevent the development of a continuous ground layer. Undoubtedly, however, there exists competition for moisture between trees and grassland, as the central roots of the trees frequently do not succeed in penetrating the hard and dry clay pan which they encounter at shallow depth. It is therefore characteristic to observe e.g. in areas where woodland is being cleared, that trees possess a heavy central root which makes a right angle there where the massive clay pan is encountered. And accordingly also the 'true' lateral roots are confined to the upper $(30-40 \mathrm{~cm})$ horizons.

The major types of grazing resource and their distribution are shown in the following map (Map 2). The symbols used refer to the structure of the main grassland types. On the following pages an account is given of the natural conditions which characterize each zone and of the types of grassland that were recognized.

Zone 1. Except for a narrow zone of well-drained lateritic and podsolic soils along the Paraná this area in northwest Corrientes is characterized by an undeveloped drainage system. The general topography is flat with an irregular surface as a result of numerous small ponds and rounded lakes. Parallel low ridges which were formed when courses of the Parana used to flow through this former delta, are obvious in the field and clearly show on aerial photographs. Holocene deposits, consisting of clays and inert quartz sands form the parent material and very acid sandy Regosols over clay are the predominant soil type. The depth of the sands is variable, giving rise to permeable, deep sands on the dune-like ridges, shallow sands with a high water table over clay on the very gentle slopes, and wet clayey soils in the lowest parts of the landscape.

The vegetation of this zone is open grassland with scattered groups of the Yatay palm (Butia yatay) in places on deep sandy ridges. Other palms found in this area and which are more adapted to poorly drained sites are Copernicia alba, up to $20 \mathrm{~m}$ tall, and a dwarf variety of the Yatay palm, reportedly common in the northern sector of this zone, namely $B$. yatay var. poni.

The land is mostly used for extensive grazing by cattle and to a lesser extent also by horses, whereas limited areas are planted with crops such as citrus, tobacco, cotton and rice (the latter mostly on river floodplains or in backswamps).

The grasslands are of two major types, namely coarse, tussocky grasslands and medium tall grasslands. The first type, found on shallow sandy Regosols and on wet clayey soils consists of coarse tussocky grasses, sedges and reeds. Predominant species are Andropogon lateralis and Bulbostylis capillaris (a sedge) and in addition a limited number of other species may be present, such as Digitaria swalliana, Axonopus suffultus, Eragrostis bahiensis, Paspalum plicatulum, Paspalum guaraniticum, Panicum hians, Luziola sp. and Eriochloa montevidensis. Because of the high water table year-round grazing is provided by these grasslands, which are of poor to fair quality, however, due to the large proportion of unpalatable and poor herbage. Around $25-30 \%$ of the 
ground cover is formed by sedges. The major grass component, Andropogon lateralis, is a species which rapidly matures producing dry, coarse flower stalks which prevent the grazing animal from reaching the more tender and lower growing species. Another species, the identity of which is still uncertain (probably Sorghastrum agrostoides), apparently is a common species in the wet grasslands in the northwest sector of this zone.

The second type of grassland, which is found on the excessively well drained, deep sandy Regosols, is a medium tall grassland with the drought resistant grass Elionurus ( $E$. candidus and $E$. viridulus) as characteristic species. The average composition of these grasslands is illustrated by the following field data: Elionurus spp. 33.9\%; Hypogynium virgatum 20.7\%; Axonopus suffultus $15.2 \%$; Paspalum notatum $11.0 \%$; Sporobolus poiretii 4.0\%; Paspalum sp. 3.7\% ; various (Aristida, Eragrostis, Setaria, Stipa) $2.1 \%$; forbs $2.4 \%$; bare soil $7.0 \%$.

It is common practice to periodically burn these grasslands to remove dry, unpalatable herbage, but even in a young growing stage the main species, Elionurus spp., is very unattractive to grazing cattle because of its strong taste.

Little improvement in the grazing industry of this zone is possible except for the implication of improved grazing techniques aiming at the optimal use of the two different types of grazing land during dry and wet periods. Because of the poor fertility status and moisture relationships of by far the most soils, species introduction into the natural graslands with the idea to improve their feeding value would only be feasible after drainage and fertilization. This would, however, require further agronomic studies including the evaluation of the costs of such techniques and of net returns. Some of the uncharacteristic better drained alluvial land included in the general area, mainly found along the Paraná, might be suitable for intensive fodder-crop production with species such as Panicum maximum, Pennisetum purpureum and tropical and subtropical legumes. Several of these species have been under observation for some years in the introduction garden of the regional experiment station near Corrientes city and look promising.

Zone 2. This area is the least productive as regards land-use. It is also the most heterogeneous and inaccessible area within the region. Conditions of soil and vegetation are accordingly known in very general terms only. It forms part of the same geomorphological region as the previous zone, namely of the former delta of the Paraná, with Holocene deposits. Vegetation and soils of the marshes, swamps and lakes, which characterize the region, belong to aquatic and subaquatic types. Some of the higher land is used for subsistence agriculture (rice, citrus, cassava). Grazing is of little or no importance.

Zone 3. A very flat topography characterizes this extensive area which reaches from the Miriñay river and the eastern border of the 'esteros' (Zone 2) up to the Uruguay valley. Continental sediments of fluvio-lacustrine origin, combined with the flat topography, have given rise to poorly drained, Gray Hydromorphic and Humic Gley Soils, associated with planosolic soils found on slightly convex crests and on the valley slopes of drainage depressions and rivers, where these soils merge with saline or alkaline soils of the regularly flooded valley margins. Those valley margins carry a woodland vegetation, with tree species characteristic of the saline-alkaline conditions, such as Aspidosperma quebracho-blanco, Prosopis nigra, Maytenus vitis-idaea, mixed with tall cacti of the genus Cereus. The crusty soil surface, partly covered by algae and moss (Selaginella sellowii), carries a sparse vegetation of dwarf herbs such as the grasses $M$ icrochloa 
indica, Tripogon spicatus, Sporobolus pyramidatus and forbs (including some legumes) such as Cressa truxillensis; Croton cf. gnaphalii; Arachis cf. villosa; Desmodium canum.

The vegetation characteristic of this zone consists of treeless grassland which is locally called 'malezal' (Fig. 1). The soil surface in this type of grassland has a rough, hummocky micro-relief with individual hummocks in strongly developed malezal of $40 \mathrm{~cm}$ high, more or less evenly spaced, 10 to $20 \mathrm{~cm}$ apart. Water stands between the hummocks during the greater part of the year (after rainy periods) as a result of the very stiff and impermeable subsoils which are usually dry and may be calcareous, particularly in the southern sector of this zone (Purnell, 1969). An active soil fauna of worms, ants and termites has frequently been found in these mounds (Purnell, 1969). Part of their role is undoubtedly that in this semi-permanently water-logged or inundated environment they create conditions (by aerating and mixing the soil) which enable plant growth. The type of vegetation developed under these conditions is a tall, tussocky grassland dominated by Andropogon lateralis. Sedges, as may be expected for such an environment, are usually well represented, contributing with 10 to $30 \%$ to the total cover. Bare soil in these grasslands may be 10 to $40 \%$. Additional species which, though present in smaller quantities and often escaping the eye, including that of the grazing animal, are characteristic of fthese communities are hygrophytic species such as Panicum milioides, Axonopus argentinus, Eragrostis bahiensis and Luziola sp., and forbs such as Dichondra repens, Hydrocotyle sp., Cuphea glutinosa and Polygala mollugerifolia.

Variation within this type of grassland is caused by differences in flooding conditions, namely in length of time and depth of the inundations. In one direction they merge with tall, permanently wet grass (Panicum prionitis, $P$. grumosum), reed and floating aquatic communities, while in the other direction a succession takes place towards dry upland communities (such as the Elionurus grasslands of zone 4). The slightly elevated convex crests found in this landscape and the valley heads with better external drainage but with compacted, planosolic soils carry short grassland forming an incomplete cover, partly as a result of overgrazing. Cattle use these hard and dry grounds for resting. As is the case with similar grasslands of other areas (e.g. of Zone 1) burning is the only method of managing Andropogon grasslands. It is under the actual conditions the only way in which excess herbage can be removed as the irregular surface prevents the use of tractor-drawn implements. Drainage of these lands would be very costly. Inundations are the result not of river overflow but of precipitation which in this area may be 1200 to $1400 \mathrm{~mm}$ per annum. The lack of both internal and external drainage, and an excess of rainfall over potential evapotranspiration further explains the existing conditions. Drainage would therefore also have to be followed up by the establishment of such grassland or crop as adapted to the newly created ecological conditions.

Zone 4. This zone in the northeastern sector of Corrientes forms the extension in southern direction of the 'Sierras de Misiones' which mainly consist of Triassic basalts. It is an area with small rounded hills, acid and infertile lateritic soils and a more luxurious, tropical vegetation. Important agricultural crops grown in this area are tung, tea and yerba mate (Ilex paraguensis). The average altitude of the hills is around $100 \mathrm{~m}$ above sea level, gradually rising in northern direction towards Misiones. Hilltop soils, well to excessively well-drained, have strong red and reddish brown colors and it is normal to find a catenary sequence of well-drained lateritic soils on the crests towards podsolic, and Low Humic Gley soils on slopes and on the extensive, flat drainage 
floors. These drainage floors show 'malezal' development with the type of grassland as described for Zone 3.

While remnants of Subtropical Forest (a formation which once must have covered larger areas) are common, the characteristic vegetation of the hills is presently a mediumtall grass savanna,dominated by Elionurus. This grass forms bending tussocks, contrary to the erect-growing Andropogon lateralis tussocks which dominate the second type of grassland found on ill-drained soils.

An important characteristic of both types of grassland is the presence of some sodforming bottom grasses which become increasingly important in the grasslands found in intermediate positions of the landscape, where conditions are permanently moderately humid. The Andropogon grassland of such sites has a much more heterogeneous composition and also a better grazing value than the more simple grass-sedge communities of the proper marshlands. They may contain up to 25 or $30 \%$ of Axonopus compressus. Apart from some 10 to $20 \%$ of sedges which this more mesophytic subtype contains, a number of other grasses and forbs are found, such as Schizachyrium, Paspalum, Eragrostis, Piptochaetium, Aristida, Bothriochloa, Rottboellia, Sporobolus, Oxalis, Chaptalia and Eryngium. Finally they usually contain a certain amount ( 3 to $10 \%$ ) of native legumes: Trifolium polymorphum, Mimosa, Cassia, Desmodium, Arachis, Vicia and Indigofera.

In another subtype, which is found in an environment slightly drier than the previous type, we find that Paspalum notatum is the main associated species. For such communities sedges are atypical.

A similar but inverse sequence of subtypes is found for the Elionurus grasslands, along the gradient from dry to moist. The grazing value of both grassland types is low when the major species are allowed to dominate and mature. Utilization should therefore aim at keeping the coarse growth down to a minimum while encouraging development and utilization of the better undergrowth. Controlled burning to remove unpalatable, dry top growth, followed by improved grazing techniques, by which use is made of the different qualities during dry and wet periods of the two types of grazing resource, would be recommendable. Tropical and subtropical grass and legume introductions may play an important role in the future.

Zone 5. Conditions within this area are rather complex but as such present good examples of edaphic control on other environmental factors. The gently undulating landscape is characterized by the presence of rock outcrop which is particularly common in the area between Mercedes and Curuzú Cuatiá (see Map 1). The line connecting these two towns forms the divide between the waters of the Parana and the Uruguay and the highest altitudes of the region are recorded here : 100 to $140 \mathrm{~m}$ above sea level ${ }^{1}$.

The basic pattern consists of a sequence of rocky crests with Triassic sandstone exposed and near flat terraces with deeper, compacted soils, separated by short, somewhat steeper slopes with rock outcrop or with shallow soils over rock. This gives rise to two completely different habitats. Firstly there are the rocky slopes with sandy lithosols. Precipitation and run-off collects here, the rock acting as a barrier and so creating marshy conditions. Secondly there are the flat terraces with compact, dry planosolic soils. The first environment with moist sandy soils carries Andropogon tussock grassland, the second environment a short grassland which is very sensitive to drought and

1 However there is one exception. From the flat plains of Zone 3 the 'Tres Cierros' ('Three Peaks') rise up as ancient remnants. These peaks, which consist of Triassic sandstone, reach $179 \mathrm{~m}$ above sea level. 
overgrazing, characterized by Paspalum notatum and Aristida spp. Frequently the latter type is characterized also by many small forbs (Convolvulaceae; Rubiaceae).

Away from the more eroded areas with sandstone outcrop, further down in the landscape, basalt outcrop and soils derived from basalt are common, but other geological material of Pliocene and also of Pleistocene origin forms part of the parent material as well. Conditions within this zone are therefore far more complex than this general discussion might suggest. Summarizing, it may be stated that in this zone, where apart from cattle breeding the breeding of wool-sheep is important - cattle and sheep normally grazing together - a vegetation mosaic is found with two contrasting types of grassland, forming an intricate pattern. This pattern is based on permeability and depth of the soil. Better medium-tall grassland is found on soils derived from basalt and from Miocene and Pleistocene (loess) deposits. Many of those soils were tentatively classified as Hydromorphic Brunizems while Grumusols do occur as well (Purnell, 1969).

Where the depth of the Pleistocene sediments increases the woodland vegetation becomes more important (Zone 6). The presence or absence of woodland in certain areas, however, is not explained by one single factor of the environment only and clearing and burning, for instance, have no doubt also played an important role.

Zone 6. This region comprises most of the flat to gently undulating wooded area in the centre of Corrientes province and in the northern and central parts of Entre Ríos. All of this area is covered by Pleistocene sediments, mostly loess redeposited by water. Also 'primary' loess is found throughout this area but particularly in the western sector of this area, towards Paraná. Soils are mostly intergrades of Grumusols, namely Hydromorphic and Planosolic Grumusols, whereas intergrades between Grumusols and Brunizems are found in the north, along the boundary with Zone 5, and in the south, along the boundary with Zone 8 .

Included with this area is periodically flooded land, comprising the wide flood-plains of Corrientes river, and of the Guayquiraró and Mocoretá rivers which form the boundary between Corrientes and Entre Ríos. Those floodplains are covered by Holocene and recent alluvium. The vegetation consists of tall grass and reed communities (Panicum prionitis, $P$. grumosum, Spartina montevidensis, Cyperaceae and Juncaceae), thickets (Acacia caven; Geoffroea decorticans) and saline, short grass communities (Distichlis, Sporobolus pyramidatus, Cynodon dactylon, Portulaca sp., Euphorbia spp., etc.).

A major characteristic of the grumusolic soils in this area is their relative shallowness. Calcareous profiles as well as profiles with a high sodium content are common. The palm Trithrinax campestris has proven to be a reliable indicator species for such conditions, characterized by poor drainage and periodic flooding (puddled sites). This is a feature throughout the area, wherever wide flat divides and interfluves are found.

Much has been published already about the dark clays called Grumusols, Vertisols, etc. (see e.g. Dudal, 1967). Their main characteristics may be summarized as follows: They are heavy-textured, dark-gray to black soils which due to the montmorillonitic type of clay mineral and under the influence of a warm climate with alternate dry and wet periods, shrink and swell. They often show wide cracks when dry. Good chemical properties but rather unfavourable physical characteristics such as massive dense subsoils and low permeability are other important characteristics. As a result of internal movements, the Grumusols frequently show gilgai microrelief which in the Mesopotamia region may be of two main types, namely lineair or hogwallowing gilgai. Lineair gilgai is found on sloping land with slopes of at least $2 \%$, and the second type, the irregular or hogwallowing gilgai, is found on flat or nearly flat land. Both types are 
usually easily recognizable on the ground as well as on aerial photographs as a stripy, fingerprint-like pattern in the case of lineair gilgai, and as a spotty, measle-like pattern in the case of irregular gilgai. That the gilgai is also recognizable on aerial photographs is due to striking differences in vegetation and, particularly in the case of hogwallowing gilgai, to differences in soil humidity status. As regards the soils indeed two completely different soils are found side by side, namely deep acid soils with clay B-horizons and a frequently planosolic profile in the lows of the lineair gilgai, towards profiles with signs of hydromorphism in the case of irregular gilgai in the puddles. Shallow, dry and calcareous soils of lighter (brownish) colors are found on the mounds and rises of the gilgai (Purnell, 1969).

The typical vegetation of these two environments is a short grassland consisting of more mesophytic species (Paspalum notatum, Rottboellia selloana, Panicum milioides, Eragrostis bahiensis, Eriochloa montevidensis, Luziola sp., Dichondra repens, Oxalis spp., Sisyrinchium spp., Cyperaceae) found in the depressions of the gilgai, and a more open, short to medium tall grassland with drought-resistent species, such as Bouteloua megapotamica (very characteristic), Stipa, Piptochaetium, Aristida, Eragrostis spp. and Bothriochloa laguroides, and a number of taller weeds and small forbs, such as Eryngium, Baccharis coridifolia, Richardia stellaris and Cressa truxillensis on the mounds of the gilgai. Legumes, if present, are also characteristically found on the rises (Trifolium polymorphum, Medicago polymorpha, Galactia marginalis). In a general way it may be stated that native legumes are more common and represented by a greater number of species in the northern sector of this zone than in the southern part, in Entre Ríos.

In the above description one of the most characteristic features for this area was discussed with the emphasis on edaphic conditions. Site differences are correlated, however, with a number of other factors as well, such as type and density of woodland vegetation (a feature which is much affected by past and present exploitation) and local topography. Textural variations in the profiles of the soils belonging to the order of

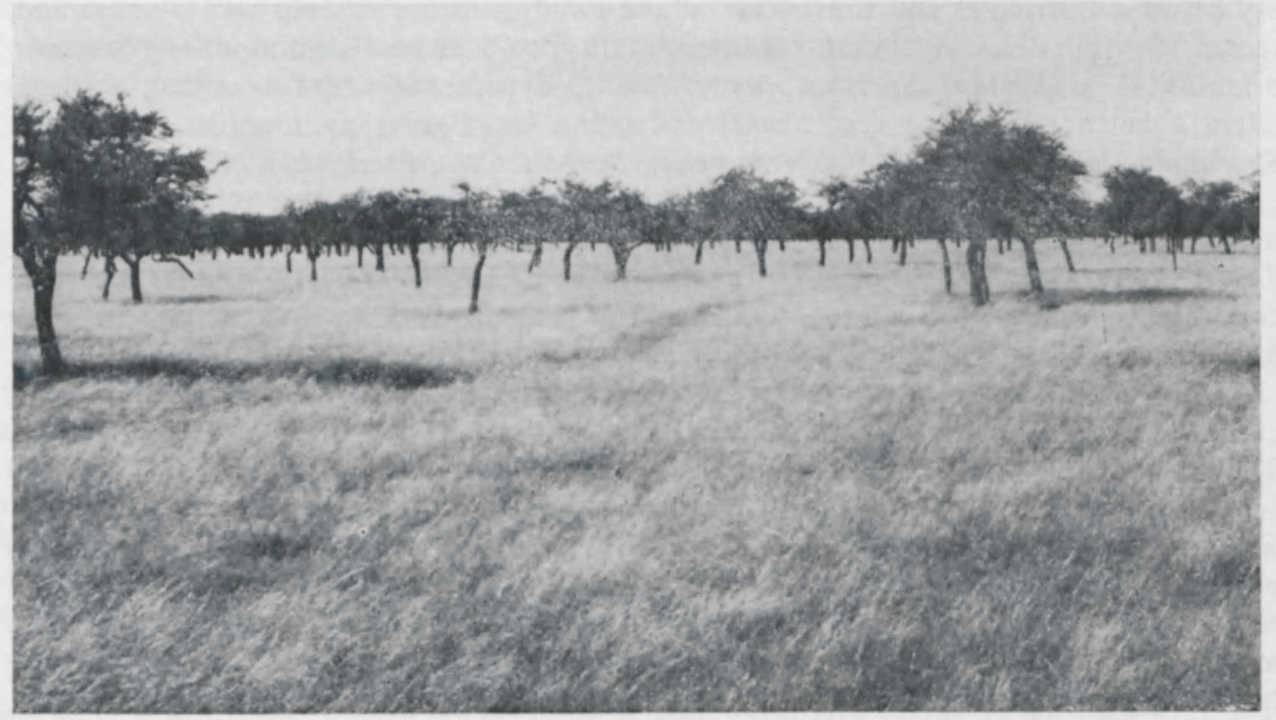

Fig. 2. Exploited, sclerophyll woodland (Prosopis algarobillo - Acacia caven) and medium-tall grassJand (Aristida - Paspalum) typical for Zone 6. 


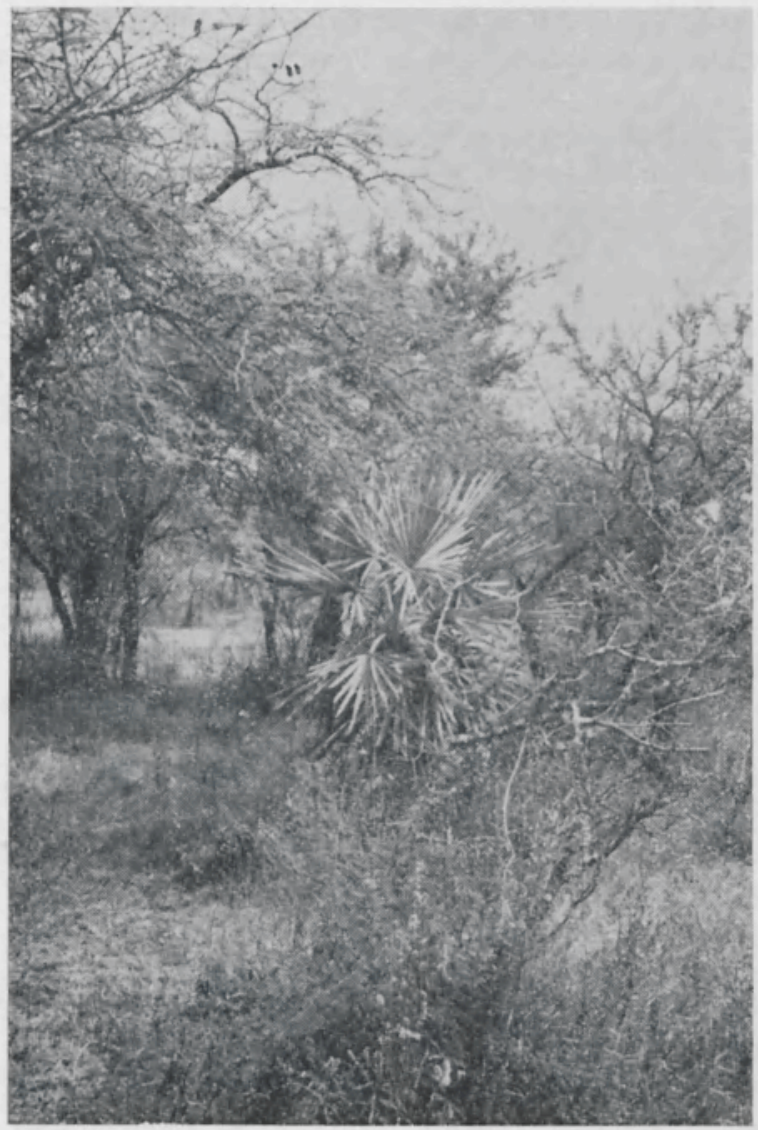

Fig. 3. Sclerophyll woodland typical for the centre of the region. The small paim in the foreground is Trithrinax campestris, often abundant in this area and reaching a height of $8-10 \mathrm{~m}$. Note the irregular gilgai (Zone 6).

the Vertisols are therefore strongly correlated with the grazing value of the grasslands and the agricultural potential of the soils of a particular site. Finally, past and present grazing practices are of greatest importance with respect to the condition of the vegetation cover (Fig. 2 and 3).

Zone 7. This region in the north-centre of Entre Ríos is characterized by a flat to gently sloping topography. Soils, formed from Pleistocene sediments, are poorly drained $\mathrm{Hy}$ dromorphic Grumusols in the marshy uplands of wide, flat divides, Planosolic Grumusols and other Grumusol intergrades on the very gentle slopes towards the little-incised drainage depressions. Land-use is almost exclusively confined to grazing of breeding cattle and wool-sheep in the most northern sector where dirty woodland and thickets are found. In the remainder of this zone the grazing resource consists of old secondary grassland and rice fallow. Here, apart from breeding of cattle and wool-sheep some fattening of cattle is being accomplished.

The wet grasslands of the northern sector are medium-tall with a large proportion of sedges and tall forbs. Some of the characteristic species are Schizachyrium intermedium, Chloris berroii, Bromus auleticus, Eriochloa montevidensis, Baccharis spp., 
Eupatorium cristeanum, Eryngium spp., Heimia salicifolia and Teucrium cubense.

The woodland and thickets are composed of species such as Acacia caven, Parkinsonia aculeata and Aloysia gratissima.

Old secondary grassland, found on land previously cultivated with sorghum, linseed or oats, consists of short grassland with Paspalum notatum and Axonopus compressus as the principal species, associated with Stipa neesiana, Aristida spp. and forbs such as Baccharis coridifolia. Small forbs of many different species are common.

Rice land is usually cultivated for 2 to 3 years under a single crop (irrigated from boreholes) after which cattle and sheep are turned in. In the early stages tender species dominate such as Luziola, Leersia, Paspaluum distichum, Cynodon dactylon, Erichloa montevidensis and Lolium multiflorum, weeds such as Aster squamatus, Gerardia communis, Heimia salicifolia and Plantago taraxoides and several sedges. Gradually the harder perennial and common stoloniferous species take over, such as Paspalum notatum, Piptochaetium spp., Stipa spp., Sporobolus poiretii, Paspalum plicatulum and Eragrostis bahiensis.

The most poorly drained areas, which never have been ploughed, are covered by medium-tall grassland with species such as Schizachyrium, Tridens brasiliensis, Paspalum cf. bruneum and Chloris berroii, and lower grasses such as Paspalum, Rottboellia and Setaria. Tall forbs (Eupatorium candoleanum; Baccharis coridifolia) are common in places.

With its grasslands of varied composition, its marsh and rice stubble land, this zone has a good potential for further development. Annual pastures such as oats, Phalaris minor and Melilotus are fairly common within this area. Lotus corniculatus is also tried in many places, but with inconsistent results.

Zone 8. This area and to a slightly lesser extent also the following zone, forms the agriculturally most advanced part of the region. It is treeless, undulating country. The streams have erosive channels, draining southwards into the Paraná delta. Loess sediments are important in this area and soils are Brunizems, with Brunizem intergrades towards Grumusols in its eastern sector. Rainfall, ranging from 900 to $1000 \mathrm{~mm}$, is more efficiently used by those soils than by the proper Grumusols. This makes them comparable to the fertile and productive agricultural soils of Buenos Aires province (the Pampa) and apart from cash crops such as wheat, linseed, maize and sorghum this zone has some 150,000 ha of sown forage crops: luzerne, Melilotus, white clover, Phalaris and Festuca.

The principal feed source for cattle in this zone consists of unimproved short term fallow, locally called 'campo refinado' which literally means 'refined natural grassland'. Regrowth on such land usually contains good proportions of species such as Lolium multiflorum, Bromus unioloides, Paspalum spp. ( $P$. dilatatum is a major component of some of the better, moister grasslands), Stipa, Piptochaetium and Medicago polymorpha. Depending on factors such as the sort of crop previous grown, the number of years since the last crop was harvested, the type of grazing management, etc., weeds may be common to abundant (Ambrosia, Conyza, Brassica, Ammi, Cirsium, Cynara, etc.).

Additional grazing during periods of drought is found in the delta lowlands (Zone 11). More advanced techniques such as the conservation of fodder (luzerne hay; silage making) and the sowing of winter forage crops are quite common in the area but heavy rains in autumn and winter present a serious risk in areas with Grumusols, where poaching frequently prevents the utilization of the expensive fodder crops. One of the major drawbacks for the cultivation of the black soils lies indeed in irregular rainfall, 


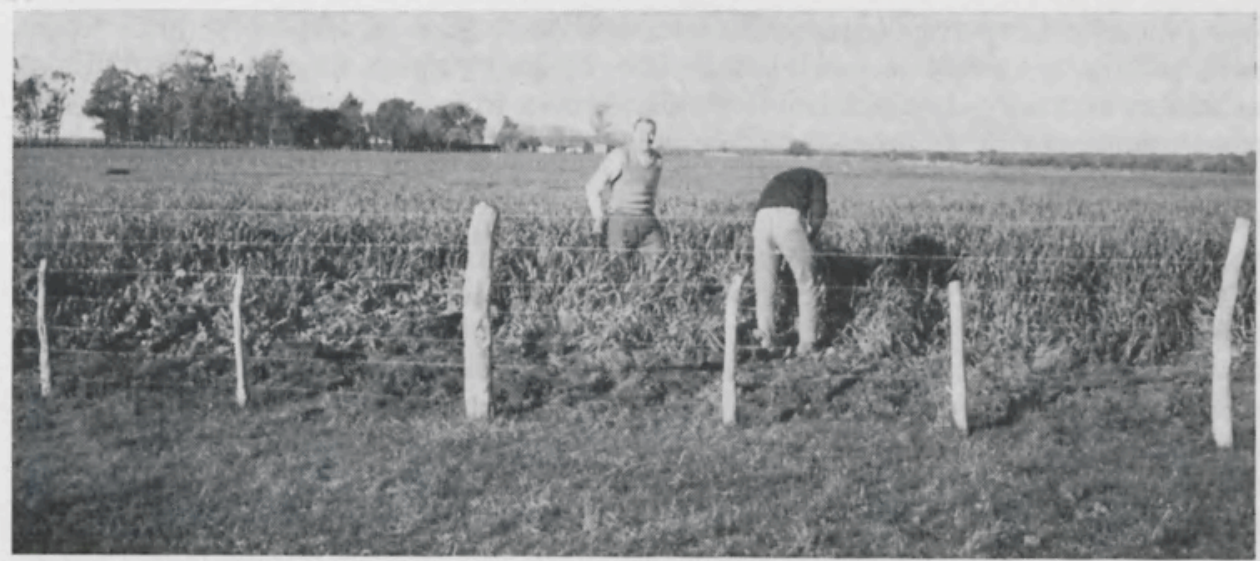

Fig. 4. A very good crop of fodder barley on land recently cleared from woodland (Zone 6).

insufficient knowledge about proper soil and seedbed preparation techniques and a general lack of planning and organization of farm operations.

Zone 9. Of all the areas discussed sofar this is the area with the largest extent of Grumusols. Gradational profiles are common: the soils have loamy surface soil textures (Purnell, 1969). This characteristic, combined with the undulating topography of the landscape resulting in a better external drainage, is an important reason for the fact that most of the land has been ploughed in the past and that agriculture is still playing an important role. Apart from the usual crops (linseed, wheat, maize and sorghum) rice is important in the northern sector of this zone.

The livestock industry throughout the area, particularly in the south, shows a tendency towards fattening of beef-cattle. Mixed grazing by sheep and breeding cattle characterizes the north.

The natural grasslands are mostly seral communities on which few studies have been carried out sofar. Typical species belonging to these communities are Ammi, Apium leptophyllum, Brassica campestris, Foeniculum vulgare, Cirsium, Cynara, Bothriochloa laguroides, Bromus unioloides, Calamagrostis montevidensis, Cynodon dactylon, Digitaria sanguinalis, Echinochloa, Lolium multiflorum, Panicum (bergii), Paspalum, Piptochaetium spp., Stipa spp., Setaria geniculata, Sorghum halepense, and legumes such as Adesmia, Medicago arabica, $M$. polymorpha, Rhynchosia spp., Vicia spp. and Trifolium polymorphum.

Apart from the great variation which characterizes these grasslands and which is due to their history, there is further differentiation which is caused by the topography and corresponding edaphic differences. A similar catenary sequence from crest to valley bottom as described for Zone 6 and 7 is found hcre. Irregular gilgai is not very common due to the undulating topography, but lineair gilgai is encountered throughout the area. Planosolic and in places saline-alkaline soils are found on lower slopes, which are periodically flooded. These soils carry a poor, sparse ground cover, but alluvial soils on wider flood-plains carry grasslands which represent a valuable dry season grazing resource. Most of the valleys of the rivers and smaller streams still carry protective woodland and narrow fringing forest. Serious gully erosion is therefore not nearly as common as it is in the previous zone. 
Zone 10. Along most of the region's eastern border a zone of variable width is found which outlines the previous, much wider valley of the Uruguay. This area with red and reddish-brown sandy clay and gravelly soils, formed from ancient alluvium, has a dissected topography. It is primarily an agricultural zone and citrus is the major crop. Some olives are grown, whereas plantations of eucalypts and pine are found throughout the area. Land-use practices are in general more intensive, with garden cropping (water melons, vegetables, peanuts, potatoes) and a rather thriving poultry industry around the major towns (Concepción del Uruguay, Concordia, Chajari, Monte Caseros). Cattle farming in this zone is also carried out on smaller units and more intensively.

Natural grassland is found on the shallower sands over clay and on low, seasonally wet areas along the Uruguay river and its tributaries. Typical pasture types for this zone are medium-tall grasslands, with tussock grassland (Andropogon lateralis) and tall reeds (Scirpus, Typha) found in wetter areas.

Major species are Schizachyrium intermedium, Axonopus, Piptochaetium, Stipa, Briza, Aristida, Eragrostis, Bothriochloa, Rottboellia, Elionurus, Rhynchelytrum and Tridens. Native legumes are fairly common: Vicia, Lathyrus, Phaseolus, Rhynchosia and Medicago. In comparison with the grasslands on the black clays these grasslands show a more regular production throughout the year, without the sharp drop during periods of drought, characteristic for the grasslands on Grumusols. This is caused by the greater permeability of these lighter-textured soils as a result of which they are able to absorb and store more water than the heavy, cracking clays, which seal off their surface after rains. It has also been observed that spring growth tends to be slower on the clays than it is on the lighter-textured soils. Such differences in behaviour and productivity between grasslands on these two different soil types would merit further studies in order to decide on proper use and management techniques.

Zone 11. Conditions within this last zone to be discussed are too variable and known in too little detail as to justify more than a brief discussion. Soils are mixed Alluvials and Sub-Humic Gleys, while there are limited areas with Half Bog and Saline Alluvial soils (Bonfils, 1962; Purnell, 1969). Inundations and a permanently high water table are the general feature. The greater part of the area is covered by tall herbaceous swamp communities with gregarious species such as Scirpus californicus, Typha angustifolia, Eryngium pandanifolium, Panicum prionitis and $P$. grumosum, intermixed with aquatic communities and relatively drier communities which provide good grazing during spring and summer months, in times when upland areas on Grumusols are producing little fresh growth (during drought periods).

Finally there is dense riveraine forest (and thickets) along active and abandoned river arms.

The major use of these lands is for forestry purposes: extensive areas in the southern and southeast sectors of the delta are covered by plantations of willow (Salix alba var. alba), poplar (Populus deltoides) and pine (Pinus eliottii; P. taeda).

Rough grazing is of secondary importance throughout the area, with seasonal fattening in the northern delta.

\section{Further research required}

The livestock industry though occupying the great majority of the lands of the Mesopotamia region is characterized by husbandry practices both in the pasture and animal sector, which are traditional and extensive. Paddock sizes range from 800 ha and more 
in the north to 100 ha and less on the more advanced and intensively managed properties in the south. Under those conditions it is difficultt to achieve controlled grazing.

The interaction of climatic and edaphic conditions gives rise to sharp seasonal fluctuations in herbage production with maxima during spring and autumn, and pronounced minima during the dry summer months (June-August). Grazing is year-round, with stocking rates ranging from $0.7 \mathrm{AU}$ per ha on the better types of natural grassland to $0.5 \mathrm{AU}$ or less on the poorer grasslands.

Prolonged mating seasons are commonly practiced, and heifers, which have a breeding life of about 10 years, are first mated at ages between 2 and 3 years and older. Calving and lambing takes place from winter to early summer and so mating and calving-lambing periods tend to coincide with periods during which the productivity of the natural range is at a low point (Hutchison, 1968). Average calving rates range from 50 to $60 \%$, reaching 70 to $80 \%$ in individual cases, mostly again in the southern parts of the region. The fattening of young steers takes from 2 to 4 years and more when grazed on unimproved natural grassland.

In the foregoing pages an outline was given of the major types of grassland and the ccological conditions under which they occur. The present worldwide demand to increase agricultural and livestock production and the temptation which many of the developing countries are now facing, namely to invest their capital and manpower in industry more than in agriculture, carries with it the danger of further upsetting the natural balance. A continuously rising local and export demand for meat will in the case of Argentina inevitably lead to a further degradation of the grazing lands, as long as insufficient knowledge about the primary resources is preventing the technification required to meet the increasing demand. And apart from basic knowledge of the grazing resource as such there is a need also for more information and factual knowledge about costs and returns of new techniques and practices under the actual conditions, both ecological and economic.

Further investigations are needed on more general problems such as the productivity and nutritive value of different pasture types, together with a study of the seasonal fluctuations of these values, and on the desirability and possibility of improving the natural grasslands.

Solutions to the above problems should undoubtedly receive priority in future research programs. But besides solutions to technical problems there are other barriers which will tend to slow down progress and which accordingly would have to be considered, such as:

a. The infrastructure of the region which is such that transport is risky and costly. More paved trunk roads and better communications with the rest of the country, particularly with the south, are of primary importance;

b. The region's isolated position has created a feeling of independence amongst the farmers and land owners, and this is finding an expression for instance in the way life and work is organized on the 'estancias'. This way of life is largely traditional and, attractive and fascinating though it is, is not in line with present-day demands and concepts about farm management and farm economy;

c. Actual prices of farm equipment, materials and fertilizers compared with prices the producer receives for livestock products (meat and wool) on the one hand and the value of land on the other, are such that insufficient incentives exist for the farmers to make improvements and raise production through capital investment.

As long as such factors of socio-economic order are not given full consideration in 
future planning and research, technical recommenjations will most likely fail to make more than an incidental impact on the region's otherwise promising livestock industry.

\section{Acknowledgments}

Information contained in this paper is based on $31 / 2$ years of work as Grassland Ecologist (Survey) and member of the FAO/INTA project Arg. 18, Proyecto de Investigaciones y Demostraciones en la Producción de forrajes y Manejo de pasturas, Concepción del Uruguay, Entre Ríos, Argentina. I am indebted to the Directors General of the Food and Agriculture Organization, Rome, and of the Instituto Nacional de Tecnología Agropecuaria, Buenos Aires, for their permission to publish this paper.

Helpful criticism and suggestions by Dr H. G. Hutchison, Project Manager of FAO/ INTA project Arg. 18, who reviewed the manuscript, is gratefully acknowledged. I would like to thank Dr C. Wayne Cook, Head of the Range Science Department, Colorado State University, Fort Collins, Colorado, USA, for reviewing the paper.

It is further a pleasure to remember and acknowledge the collaboration received during the course of the Survey from other FAO and INTA Staff, especially from Mr Maurice Purnell, FAO Soils Specialist, Ing. Agr. Alicia Ferrarotti, Ing. Agr. Mario Landi and Ing. Agr. Norberto Hein of INTA, Concepción del Uruguay.

Grateful acknowledgment is made to Dra. S. B. Sorarú, Botanist of the Agricultural Experiment Station at Concepción del Uruguay, and to the Staff of the Darwinian Institute at Buenos Aires, for identification of plant material.

\section{References}

Banco Ganadero Argentino, 1968, La producción rural Argentina en 1967. Buenos Aires.

Bonarelli, G. \& E. Longobardi, 1929. Memoria explicativa del mapa geo-agrológico y minero de la Provincia de Corrientes. Corrientes.

Bonfils, C. G., 1962. Los suelos del Delta del Río Paraná. Instituto de Suelos y Agrotéenia. Buenos Aires.

Buringh, P., 1968. Introduction to the study of soils in tropical and subtropical regions. Pudoc, Wageningen, Netherlands, pp. 118.

Cabrera, A. L., 1953. Manual de Ja Flora de los alrededores de Buenos Aires. Buenos Aires.

Cabrera, A. L., 1963. Flora de la Provincia de Buenos Aires, Parte VI: Compuestas. Colección Científica del INTA. Buenos Aires.

Cabrera, A. L., 1965a. Flora de la Provincia de Buenos Aires, Parte IV: Oxalidáceas a Umbelíferas. Colección Científica del INTA. Buenos Aires.

Cabrera, A. L., 1965b. Flora de la Provincia de Buenos Aires, Parte V: Ericáceas a Caliceráceas. Colección Científica del INTA. Buenos Aires.

Christian, C. S., 1958. The concept of landunits and landsystems. Proc. 9th Pac. Sci. Congr. 20:74-81.

Christian, C. S., 1959. The eco-complex and its importance for agricultural assessment. Biogeography and Ecology in Australia.

Christian, C. S. \& E. A. Stewart, 1953. General report on the survey of the Katherine-Darwin Region, 1946. CSIRO Land Research Series No 1. Melbourne.

Cordini, I. R., 1949. Contribución al Conocimiento de la Geología Económica de Entre Rios. Dirección General de Industria Minera.

Dudal, $R_{1}, 1965$. Dark clay soils of tropical and subtropical regions. FAO Agric. Development Paper No 83. Rome.

Hutchison, H. G., 1968. Problem analysis by the Project Manager of the Project for Research and Demonstration on Forage Production and Pasture Management in the Mesopotamia Region, Argentina. Internal report.

Hutchison, H. G. \& J. F. Frame, An 'animal unit' system of recording to measure output and plan future utilization of pastures. (In press.)

Purnell, M. F., 1969. Personal discussions and Tech. Rep. No 1 of the FAO/INTA Project Arg. 18.

Teruggi, M. E., 1957. The nature and origin of Argentine loess. J. Sed. Pet. 27. 